\title{
Bridging Intellectual Capital and SMEs Internationalization through the Lens of Sustainable Competitive Advantage: A Systematic Literature Review
}

\author{
Elena-Mădălina Vătămănescu ${ }^{1, * \mathbb{D}}$, Elena-Alexandra Gorgos ${ }^{2}$, Alexandru Mihai Ghigiu ${ }^{3}$ and \\ Monica Pătruț 4 \\ 1 Faculty of Management, National University of Political Studies and Public Administration, \\ 012104 Bucharest, Romania \\ 2 Center for Research in Management, National University of Political Studies and Public Administration, \\ 012104 Bucharest, Romania; alexa_elena85@yahoo.com \\ 3 The Department of International Relations and European Integration, National University of Political \\ Studies and Public Administration, 012104 Bucharest, Romania; mihai.ghigiu@dri.snspa.ro \\ 4 Faculty of Letters, "Vasile Alecsandri” University of Bacău, 600114 Bacău, Romania; \\ monicapatrut@edusoft.ro \\ * Correspondence: madalina.vatamanescu@facultateademanagement.ro
}

Received: 25 March 2019; Accepted: 26 April 2019; Published: 30 April 2019

\begin{abstract}
The aim of the current paper is advance a comprehensive framework meant to bridge three major concepts, namely intellectual capital (IC), the internationalization process of small and medium-sized enterprises (SMEs) and the achievement of sustainable competitive advantage. The paper stresses upon a managerial perspective within the internationalization context, investigating the human, structural and relational capital apposite to managers or entrepreneurs. By directly addressing the relationships among the constructs, the endeavor is complementary to previous systematic reviews on similar topics which tangentially discuss the conceptual triad and thus proposes an integrative research agenda for future interdisciplinary studies straddling the fields of management, business, entrepreneurship and sustainability. In terms of methodology, a systematic literature review was envisaged, by applying a stepwise approach and multifold criteria. Over 100 scientific articles published in peer-reviewed journals were scrutinized and considered in the analysis. The literature review revealed that conceptual papers in the field are scarce despite the variety of their aims and approaches. The quantitative-based empirical studies prevail over the qualitative ones, while mixed methods research designs are scant. In terms of content, the extant studies fall short to advance research and structural models testing and assessing the specific relations among constructs and avail new research avenues focused on the underlying processes of SMEs internationalization by means of intellectual capital harnessing and sustainable competitive advantage achievement.
\end{abstract}

Keywords: intellectual capital (IC); small and medium-sized enterprises (SMEs); internationalization; sustainable competitive advantage

\section{Introduction}

The debate on the intellectual capital and the internationalization of the small and medium-sized enterprises (SMEs) is nowadays of growing interest [1-6]. A myriad of studies tends to advance exhaustive approaches on the correlations between varied facets of the two variables, pointing to the research opportunities availed by this topic [7-10]. 
The internationalization of business has become a focal point for researchers given the competitiveness and sustainability imperatives of different kinds of enterprises which are often linked to their international expansion, to entering new markets, exploiting new strategies and new assets, enhancing their knowledge, mapping entrepreneurial opportunities and pursuing sustainable competitive advantage [4,11-14]. Not only that internationalization is a way to augment organizational competitiveness and sustainability in the long run [6], but it is also a survival kit in response to the business environment challenges [1,15-17].

The internationalization decision is usually taken by the manager or business owner with a view to improving the available resources, facilitating tenable international collaborations, ultimately to achieving sustainable competitive advantage on foreign markets [11,18-23]. The internationalization process would not be efficient, even possible, without the contribution of intangible assets such as the intellectual capital which is presumed to exert significant effects on the organizational performance and competitiveness in both national and international realms [24-29]. It is in this particular point that we give credit to the propositions advanced by Cohen and Kaimenakis [30] and Korsakiene et al. [31] when discussing the role of intellectual capital as a driving force of internationalization, via their definition of IC as "the combination of knowledge-bearing intangible resources that the firm has at its disposal whose effective management impact sustainable competitive advantage" (p. 503). This perspective is in line with Jaakkola et al. [32] and Na et al. [33], according to whom the sustainable competitive advantage can be operationalized as the capitalization of the organization's valuable, rare and irreplaceable resources and capabilities which are prone to reify long-term competitiveness.

The topicality and the relevance of the addressed issues are also recently spotted by Ying et al. [34] who pinpointed a knowledge gap in previous studies in that they tend to revolve around the role of tangible resources in the success of SMEs. The researchers underscore that particularly the role of the intangible skills (i.e., intellectual capital) in relation to sustainable competitive performance has missed in prior studies, thus inviting further research to close the breach. Similarly, Januškaite and Užiene [35] acknowledged the role of IC as "the foundation for competitive growth" from a twofold perspective-accounting for the sustainable competitive advantage at an organizational level as well as for sustainable regional competitiveness. In addition to this, to the best of our knowledge, to date, no systematic reviews or bibliometric papers have been published on the topic (i.e., the triad intellectual capital-SMEs internationalization-sustainable competitive advantage) or on similar topics (i.e., different facets of the three constructs), a fact which supports the opportunity to develop a consistent conceptual framework in this vein.

Looking into all these aspects brings to the fore the importance of the multifaceted intellectual capital construct and of its relevance in the context of SMEs' international ventures all the more so as many studies describe intellectual capital as an essential factor of productivity, economic performance, and organizational competitiveness and sustainability $[6,9,36-39]$. Despite the broad array of definitions and classifications of the intellectual capital construct, the taxonomy employed in the current paper revolves around its three main dimensions, namely, human capital, relational capital and structural capital [38-41]. These dimensions are investigated through the lens of the international business literature [6,42-45] which has either explicitly, or implicitly mapped and mainstreamed relevant correlations.

The international business literature highlights various managerial orientations towards internationalization $[26,46]$, ranging from the creation of sustainable networks, foreign investments and exports $[1,11,47-50]$ to the distinction between family-owned SMEs and non-family SMEs and their own perspectives on international ventures [51-54]. In all these studies and in other related ones, in spite of the wide spectrum of approaches, there is often a component of intellectual capital which proves its influence in successful internationalization. Even though the internationalization process of SMEs, as well as the intellectual capital as an important intangible resource, have been intensively addressed, the nexus between the internationalization facets and different types of intellectual capital 
has triggered less attention. Internationalization poses multiple challenges to SMEs, still many studies offer one-factor or context-driven insights into going international [55].

Given that the extant literature review has yet to explicitly discuss the relationships between the intellectual capital, as a holistic concept, respectively of its dimensions (i.e., human, structural and relational capital) and SMEs internationalization in the quest for achieving sustainable competitive advantage, a more articulate insight into the state-of-the-art is needed. It is in this particular point that the current paper intends to bring about its conceptual contribution, filling the research gap via a systematic literature review, thus providing a more comprehensive framework. The endeavor is purposive all the more so as SMEs stand for key actors on most markets $[8,36,56]$ and their international dynamics substantively afflict the global business arena.

The paper is structured as follows: the first section describes the methodological design for the systematic literature review while the second one introduces a multicriterial approach on intellectual capital and SMEs internationalization. Thenceforth, some of the pivotal research streams bridging intellectual capital and SMEs internationalization are brought to the fore in an effort to outline the scope and focus of the studies in the field. The paper ends with the conclusions section which also integrates the original inputs and the limitation of the current analysis.

\section{Materials and Methods}

The systematic literature review was conducted in line with Webster and Watson's [57] guidelines. The choice for performing a systematic literature review over more critical types of surveys or reviews was founded on the absence of such undertakings on the envisaged topic, thus aiming at "bringing together previously-disparate streams of work to help shed light on a phenomenon" (p. XV). To this end, a systematic approach of the key variables and inherent boundaries was purposive and timely. In what concerns the latter, the units (levels) of analysis, contexts, scope of the review and implicit values have been established beforehand.

Consistent with Webster and Watson [57] (p. XVI), "the literature review is concept-centric" (as shown in Tables 1 and 2), the constructs emerging as the backbone of the organizing framework. Hence, the considered key variables referred to the main concepts envisaged by the literature review, namely "intellectual capital", "human capital", "structural capital", "relational capital", "SMEs internationalization", "sustainable competitive advantage". Switching to the main established units (levels of analysis), the search strategy focused on the managerial and entrepreneurial frame of reference, given that managers/business owners stand for key representatives and decision-makers with regard to the SMEs internationalization through the lens of a sustainability approach.

The search was limited to full-text articles published in peer-reviewed academic journals retrieved via the exploration of three online databases, that is Web of Science (Clarivate Analytics), EBSCO Business Source Complete, and ScienceDirect. The choice of Clarivate Analytics's Web of Science (WoS) as a preliminary search engine for identifying relevant sources was founded on Li et al.'s [58] specialized study published in Scientometrics in 2018, according to which WoS "is the world's leading scientific citation search and analytical information platform. It is used as both a research tool supporting a broad array of scientific tasks across diverse knowledge domains as well as a dataset for large-scale data-intensive studies" (p. 1). As concluded by the authors, WoS is used in more than 19,000 studies English-language research and review papers published between 1997 and 2017.

The inclusion of EBSCO Business Source Complete, and ScienceDirect in the search strategy revolved around the "multidisciplinary nature of most social science research questions and the large selection of social science-related databases", a fact which entails that searches must be implemented in multiple databases [59]. EBSCO Business Source Complete was considered because it was designed as "the essential research database for peer-reviewed, full-text business journals", covering 2096 active full-text journals \& magazines and 1259 active full-text peer-reviewed journals [60]. Further, ScienceDirect is Elsevier's leading information solution for researchers, covering over 3800 journals and serials, representing more than 612,000 issues [61]. By providing advanced access to peer-reviewed 
articles accepted for publication (articles in press), ScienceDirect supports the identification of potential sources of reference for the investigated topics which have not been indexed in WoS or EBSCO yet, then complementing the previous queries.

Regarding the contextual limitations, the search strategy focused on a certain type of organizations, that is SMEs, irrespective of the region or country. Further, in terms of temporal limitations, the selection criteria consisted of full text availability and the publication date of the papers - only the articles published between 2000 and 2018 were kept with a view to ensure a certain degree of topicality. The cut-off year was established based on Petty and Guthrie's assertions [62] according to which, in 2000 , there was an increasing propensity towards the IC topic both in practice and academia, a fact which was confirmed via the proliferation of thematic conferences, working papers, journal articles, etc. and via various specialized services provided by a growing number of consulting firms in this area.

In what concerns the scope of the review, the fields of interest which will be drawn upon and constitute a pertinent boundary for the explored topic and levels of analysis are business, management, entrepreneurship and economics, as the issues of intellectual capital, SMEs internationalization and sustainable competitive advantage have been recurrently and particularly discussed in these specialized domains.

Taking into considerations the aforementioned aspects, the search strategy started with the exploration of WoS online database using the Advanced Search option. The used field tag was Topic (TS), the restrictions related to document types focused on Article and Review categories while the timespan was settled between 2000 and 2018. As the goal was to retrieve papers which linked all the key variables, the Boolean operator "AND" was used (and further in the case of EBSCO Business Source Complete and ScienceDirect). As part of the search equation, although it narrows down the parameters of the exploration, confining it to a more specific demarcation, AND was employed to combine together different search terms and to retrieve results where all of them occurred. In this respect, the simultaneous search of all triads (e.g., (TS = (intellectual capital AND SMEs internationalization AND sustainable competitive advantage)) AND DOCUMENT TYPES: (Article) Indexes = SCI-EXPANDED, SSCI, A\&HCI, CPCI-S, CPCI-SSH, BKCI-S, BKCI-SSH, ESCI, CCR-EXPANDED, IC Timespan = 2000-2018; TS = (intellectual capital AND SMEs internationalization AND sustainable competitive advantage) AND DOCUMENT TYPES: (Review) Indexes = SCI-EXPANDED, SSCI, A\&HCI, CPCI-S, CPCI-SSH, BKCI-S, BKCI-SSH, ESCI, CCR-EXPANDED, IC Timespan = 2000-2018, etc.) retrieved no results, we further proceed by eliminating the third term "sustainable competitive advantage" and to look into dyads only (e.g., TS = (intellectual capital AND SMEs internationalization), TS = (human capital AND SMEs internationalization), TS = (relational capital AND SMEs internationalization), TS = (structural capital AND SMEs internationalization), TS = (social capital AND SMEs internationalization)).

These preliminary searches returned over 70 articles which conformed to the specified criteria, some of them being duplicates (falling into multiple sets). As the number of results was quite low, we proceeded by searching for more general terms as: "SMEs international networks", "SMEs strategic alliances and international collaboration", "SMEs international ventures and sustainable competitive advantage". 17 more results were thus retrieved.

The next step was to run the searches in EBSCO Business Source Complete, by defining the following search modes: Boolean/Phrase, join operator AND, limit the results to Full Text and Scholarly (Peer Reviewed) Journals, All text (TX). The searched terms were: "intellectual capital AND SMEs internationalization AND sustainable competitive advantage", "human capital AND SMEs internationalization AND sustainable competitive advantage", "relational capital AND SMEs internationalization AND sustainable competitive advantage", "structural capital AND SMEs internationalization AND sustainable competitive advantage", "social capital AND SMEs internationalization AND sustainable competitive advantage". Over 150 articles were retrieved including duplicates. Finally, by using the Advanced Search option available on ScienceDirect and the same research terms and restrictions as in the EBSCO online database, over 700 articles were identified (duplicates included). 
After removing the duplicates within each search (i.e., a certain database), the duplicates across all queries (i.e., all searched online databases), the titles of the papers and the abstracts were analyzed in relation to the purpose of the literature review with a view to decide on the papers which should be removed from the initial list as they did not fit the focus and scope of the current investigation. In the case of several articles whose titles and abstracts fell short to provide compelling or definite information in terms of thematic relevance, further content scrutiny was required and thus performed. In terms of content, the main objectives of the analysis resided in the assessment of impact and contextual relevance of the identified studies in relation to the aims of the present literature review according to three selection criteria: (a) the study addresses the relationship between the intellectual capital and SMEs internationalization in either of their dimensions, components or facets through the lens of sustainable competitive advantage; (b) the study discusses the intellectual capital dimensions (i.e., human, structural and relational capital) either explicitly, using the exact concepts, or implicitly, examining the their embedded components or hypostases (e.g., for human capital, the reference to skills, capabilities, knowledge, know-how, for structural capital, strategies and practices, for relational capital, social and business relationships, etc.); (c) the study revolves around the managerial imprint, as managers/business owners stand for key representatives and decision-makers with regard to the SMEs internationalization through the lens of a sustainability approach.

The subsequent objective was to assess the selected articles $(\mathrm{N}=102)$ via a thematic and structure analysis which would provide an articulate chart of their main coordinates, that is the focal point of the study (i.e., intellectual capital dimensions and internationalization specificity), country and sector of the investigated SMEs, type of the study (theoretical/empirical), the research design (quantitative/qualitative), year of publication, ranking of source publications, and the yearly citation trend by type of intellectual capital. Such an endeavor is consistent with Webster and Watson's [57] guidelines according to which a review should embody a state of the field, hence determining a benchmark for others who may choose to dig deeper into one or more research levels, topics, directions displaying an embryonic phase. In fact, the ultimate goal is to hew a path for others who may be inspired to pursue new or related conceptual and structural avenues from a multidisciplinary perspective.

In this front, several major research themes resulted from the examination of the extant studies, which linked the issue of intellectual capital to a wide spectrum of aspects apposite to the internationalization of SMEs and sustainable competitive advantage (i.e., the creation of SMEs networks, knowledge acquisition and development, business innovation, business performance and sustainability, achievement of sustainable competitive advantage through the exploitation of international opportunities, entrepreneurial predisposition and orientation and managerial decision-making). In short, the systematic analysis followed the stepwise approach illustrated in Figure 1.

In what concerns the values bounding the conceptual framework-in line with Webster and Watson [57]—it is our belief that the multicriteria approach of the triad intellectual capital—SMEs internationalization-sustainable competitive advantage would become a good starting point for other scholars to make sense of the accumulated knowledge in the field via the multidisciplinary perspectives, beginning with the topic's central ideas towards the related key findings and relationships among variables. Hereby, the identified research areas which mainstream the relationship between intellectual capital and SMEs internationalization through the lens of sustainable competitive advantage fall under the following main directions and/or conceptual frameworks: (a) strategic alliances, e.g., [18,36,63,64], (b) social and business networks, e.g., [8,50,51,65,66], (c) business skills, e.g., [36,46,55,67], (d) pursue or achievement of sustainable competitive advantage, e.g., $[19,36,68,69]$, (e) SMEs performance, e.g., $[13,29,50,70]$, (f) family-owned business, e.g., [24,71-74], (g) prior international experience, e.g., [55,75-77], (h) knowledge transfer, e.g., [12,78,79], (i) institutional/governmental programs, e.g., $[19,47,80,81]$, (j) business/organizational innovation, e.g., [43,81-86], and (k) the export intensity, e.g., $[36,76,82,87-89]$. 


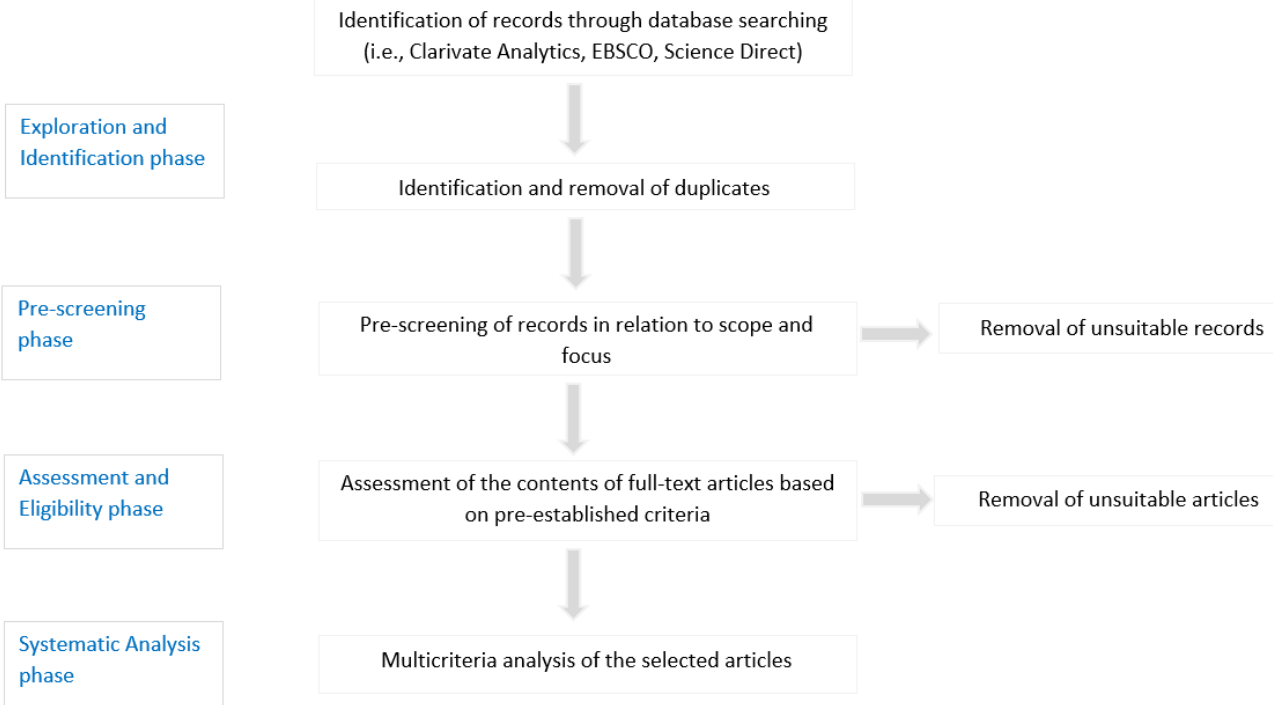

Figure 1. A stepwise approach for the systematic analysis.

Table 1. Classification of studies according to the type of intellectual capital involved in SMEs internationalization.

\begin{tabular}{ccc}
\hline No. & Type (Dimension) of Intellectual Capital & References \\
\hline 1. & Human capital & {$[1,2,4,7,11,12,26,29,46,55,84,90-92]$} \\
2. & Relational capital (social capital included) & {$[14,19,22,50,66,69,72,81,92-97]$} \\
3. & $\begin{array}{c}\text { Structural capital (organizational and } \\
\text { innovation capital included) }\end{array}$ & {$[46,82,98-101]$} \\
\hline
\end{tabular}

Table 2. Classification of studies according to the business internationalization model/characteristics.

\begin{tabular}{ccc}
\hline No. & SMEs Internationalization Model/Characteristics & References (Selection) \\
\hline 1. & Born-global model & {$[7,12,19,63,65,66,79,85,102-107]$} \\
2. & Uppsala model & {$[48,51,53,56,77,108-111]$} \\
3. & Resource-based view & {$[1,11,13,18,46]$} \\
4. & Network theory of internationalization & {$[51,64,90,95]$} \\
5. & Innovation-related models & {$[83,112]$} \\
6. & Gradual expansion & {$[86,96,113,114]$} \\
7. & Eclectic model & {$[68,74,97,115,116]$} \\
8. & Accelerated internationalization model & {$[43,98,117]$} \\
9. & Agency theory & {$[2,118]$} \\
10. & Transactional cost model & {$[67,91]$} \\
11. & New venture internationalization theory & {$[25]$} \\
12. & Supply chain internationalization & {$[82]$} \\
13. & Stewardship theory & {$[119]$} \\
14. & Dynamic capabilities view & {$[120]$} \\
15. & Dynamic experimental internationalization theory & {$[120]$} \\
16. & Early internationalization & {$[121]$} \\
17. & Late internationalization & {$[80]$} \\
18. & Concentrated hub & {$[81]$} \\
19. & Upper Echelons theory & {$[122]$} \\
20. & Franchise network internationalization & {$[123]$} \\
\hline
\end{tabular}

Given the wide range of topics covered by the selected sources and with a view to shed some light upon the investigated phenomenon, we thenceforth provide different classifications of the studies 
based on multiple criteria in order to ensure a comprehensive view on the relevant articles tackling this issue. Further, we resort to a presentation of the main research directions by correlating the dimensions of intellectual capital with diverse characteristics of SMEs internationalization.

\section{Findings}

\subsection{A Multicriterial Approach on Intellectual Capital and SMEs Internationalization}

One of the first grouping criteria resides in the focal point of the study. Here, the analysis is twofold in that contributions are systematized in relation to the type (dimension) of intellectual capital (Table 1) and to the internationalization model/main characteristics (Table 2).

In regards of the classification illustrated in Table 2, even if most of the studies focus on a certain model of internationalization, there are also papers which describe two or three models, still elaborating on one to the detriment of the others.

The examination of the relationship between the internationalization model and the type of intellectual capital reveals the fact that certain dimensions of intellectual capital may be more associated to SMEs internationalization than others. Hereby, some findings are worth to be highlighted: (a) the born-global view is associated with human capital and, secondary, with relational capital; (b) the Uppsala model advances more the structural capital (organizational/innovation capitals) and, subsidiary, human capital; (c) within the resource-based view, human capital is central, followed by structural capital and relational capital; (d) the network theory of internationalization is primarily connected to human and relational capital.

In what concerns the country of reference for the investigated enterprises, most of the empirical papers focused on European samples (more than 50\%, e.g., France, Italy, Turkey, Sweden, Portugal, England, Spain, Belgium) while the rest of them covered SMEs from the United States of America, Mexico, Canada, Australia, New Zealand and very few from Asia (e.g., China, Japan, Taiwan) and Africa (e.g., Ghana, Morocco). Next, the sectors where the studied firms operate are: electronics, manufacturing, agriculture, textiles, energy, food, wine and oil, software development, toy industry, and biotechnology. However, it should be mentioned that not all the authors have provided specific information about the exact location of the firm or its specific field of interest, this afflicting the possibility to sharply delineating across sub-categories.

The second criterion used to group the selected articles envisaged the type of study, namely theoretical versus empirical (research paper). At this level, the great majority of the contributions in the field are empirical, e.g., $[1,13,18,26,27,36,46,50,51,53,55,66,111]$ whereas theoretical papers are very scant, e.g., $[12,19,124]$.

The empirical papers particularly on one or two types of intellectual capital at most, mainly on the human capital and relational capital, and less on the structural capital. The most addressed dimension of intellectual capital is the human capital, with a focus on manager's abilities, skills, education, and international experience. Unlike the empirical papers, the reviewed theoretical works discuss more about intellectual capital in general and do not emphasize on a certain type, underscoring the internationalization process itself with implicit references to intellectual capital dimensions.

Shifting to the third criterion - the research designs of the empirical papers - the quantitative studies, e.g., $[2,7,13,29,36,42,46,56,66,116,125]$ predominate over the qualitative ones, e.g., $[4,8,51,84,90,100,114]$. Nevertheless, there are also few complex studies which advance both quantitative and quantitative methodological designs, e.g., $[26,67,71]$ and, therefore, propose more robust outputs.

The fourth criterion refers to the distribution of articles with regard to the year of publication. As seen in Figure 2, most of the selected publications date after 2011, reaching a peak in 2014. Until 2011, the studies in the field were relatively scarce, a fact which supports a growing interest for the correlation between the two variables, and its incremental importance within the context of the recent international business literature. 


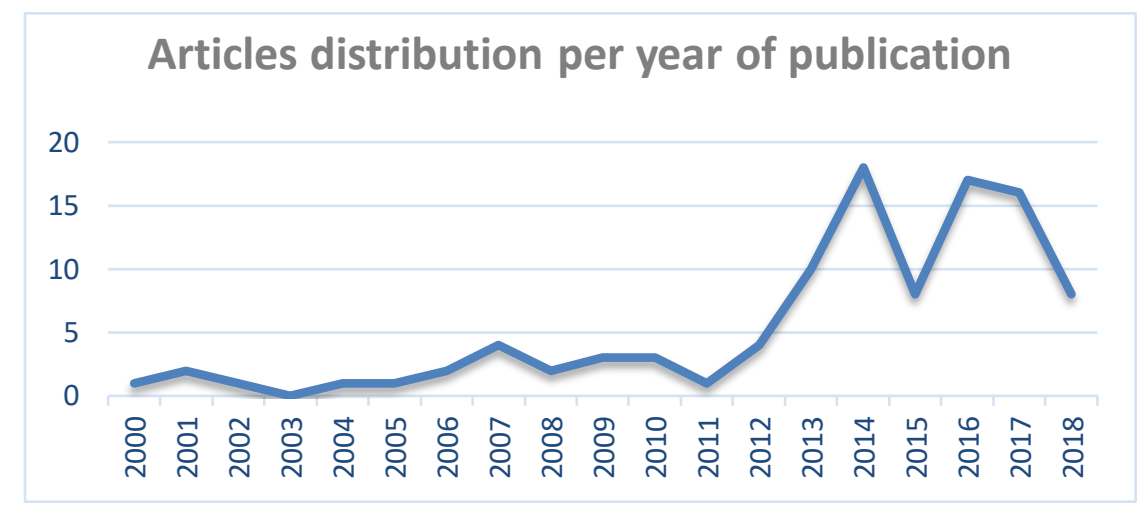

Figure 2. The distribution of articles based on the year of publication.

In order to add further information concerning the impact of the selected publications (source journals that published a certain number of articles), we created an inventory of the journals indexed in WoS, specifying relevant details, such as the impact factor (according to JCR 2017), the 5-year impact factor, the category, rank and quartile in category and the corresponding number of analyzed manuscripts (see Table 3).

Some interesting insights can be triggered from the table above. Firstly, 69 out of the 102 examined full-text manuscripts (almost $68 \%$ ) are published in journals indexed in WoS, the world's leading scientific citation search and analytical information platform. Secondly, the highest number of articles (11) were retrieved from a source journal apposite for the international business literature (i.e., International Business Review). The same applies to most of the following publications (i.e., International Marketing Review, International Small Business Journal, Journal of World Business), each of them covering 4 articles. Thirdly, more generic, yet top-ranked publications (such as Industrial Marketing Management, Academy of Management Journal, Academy of Management Review) brought forward 4, respectively 3 relevant results related to the scope and focus of the search strategy. Fourthly, as illustrated in the table, most of these publications are included in Management and Business categories, being ranked in the first two quartiles.

Remaining within the concept-centric framework of the review and making use of the number of citations provided by WoS for each indexed publication, we proceeded by investigating the correlations among the primary type of intellectual capital addressed by the papers published in a certain year and the total number of citations retrieved by these thematic articles (Figure 3). 
Table 3. Inventory of the source journals which are indexed in WoS.

\begin{tabular}{|c|c|c|c|c|c|c|}
\hline Publication Name & Impact Factor (JCR 2017) & 5-year Impact Factor & Category & Rank in Category & Quartile in Category & Number of Articles \\
\hline International Business Review & 2.754 & 3.544 & Business & $49 / 140$ & Q2 & 11 \\
\hline International Marketing Review & 2.6 & 3.446 & Business & $55 / 140$ & Q2 & 5 \\
\hline Industrial Marketing Management & 3.678 & 4.488 & $\begin{array}{l}\text { Business, } \\
\text { Management }\end{array}$ & $30 / 140,37 / 210$ & Q1 & 4 \\
\hline International Small Business Journal & 3.9 & 4.564 & $\begin{array}{c}\text { Business, } \\
\text { Management }\end{array}$ & $23 / 140,32 / 210$ & Q1 & 4 \\
\hline Journal of World Business & 3.993 & 5.019 & Business & $22 / 140$ & Q1 & 4 \\
\hline Academy of Management Journal & 6.7 & 11.254 & $\begin{array}{l}\text { Business, } \\
\text { Management }\end{array}$ & $7 / 140,4 / 210$ & Q1 & 3 \\
\hline Academy of Management Review & 8.855 & 13.277 & $\begin{array}{c}\text { Business, } \\
\text { Management }\end{array}$ & $2 / 140,2 / 210$ & Q1 & 3 \\
\hline $\begin{array}{l}\text { Journal of East European } \\
\text { Management Studies }\end{array}$ & 0.794 & 1.012 & Management & $189 / 210$ & Q4 & 3 \\
\hline Baltic Journal of Management & 1.149 & 1.103 & Management & $166 / 210$ & Q4 & 2 \\
\hline BRQ - Business Research Quarterly & 2.41 & 2.383 & $\begin{array}{c}\text { Business, } \\
\text { Management }\end{array}$ & $65 / 140,79 / 210$ & Q2 & 2 \\
\hline $\begin{array}{l}\text { Canadian Journal of Administrative } \\
\text { Sciences }\end{array}$ & 0.674 & 1.071 & $\begin{array}{c}\text { Business, } \\
\text { Management }\end{array}$ & $128 / 140,196 / 210$ & Q4 & 2 \\
\hline European Management Review & 1.25 & 2.095 & Management & $158 / 210$ & Q4 & 2 \\
\hline $\begin{array}{c}\text { Journal of International Business } \\
\text { Studies }\end{array}$ & 6.198 & 8.446 & $\begin{array}{c}\text { Business, } \\
\text { Management }\end{array}$ & $9 / 140,6 / 210$ & Q1 & 2 \\
\hline $\begin{array}{c}\text { Journal of Small Business } \\
\text { Management }\end{array}$ & 3.248 & 4.057 & Management & $48 / 210$ & Q1 & 2 \\
\hline British Journal of Management & 3.059 & 3.635 & $\begin{array}{c}\text { Business, } \\
\text { Management }\end{array}$ & $39 / 140,54 / 210$ & Q2 & 1 \\
\hline $\begin{array}{l}\text { Corporate Governance-An } \\
\text { International Review }\end{array}$ & 2.705 & 3.809 & $\begin{array}{l}\text { Business; Business, } \\
\text { Finance; Management }\end{array}$ & $50 / 140,11 / 98,66 / 210$ & Q2, Q1, Q2 & 1 \\
\hline $\begin{array}{c}\text { Entrepreneurship and Regional } \\
\text { Development }\end{array}$ & 2.791 & 4.057 & $\begin{array}{l}\text { Business, Planning \& } \\
\text { Development }\end{array}$ & $47 / 140,11 / 57$ & Q2, Q1 & 1 \\
\hline $\begin{array}{c}\text { Entrepreneurship Theory and } \\
\text { Practice }\end{array}$ & 5.321 & 8.082 & Business & $16 / 140$ & Q1 & 1 \\
\hline $\begin{array}{l}\text { Environmental Engineering and } \\
\text { Management Journal }\end{array}$ & 1.334 & 1.021 & $\begin{array}{l}\text { Environmental } \\
\text { Sciences }\end{array}$ & $171 / 242$ & Q3 & 1 \\
\hline European Journal of Marketing & 1.497 & 2.545 & Business & $95 / 140$ & Q3 & 1 \\
\hline Family Business Review & 3.824 & 7.552 & Business & $28 / 140$ & Q1 & 1 \\
\hline Global Strategy Journal & 2.121 & 5.616 & Management & $96 / 210$ & Q2 & 1 \\
\hline
\end{tabular}


Table 3. Cont.

\begin{tabular}{|c|c|c|c|c|c|c|}
\hline Publication Name & Impact Factor (JCR 2017) & 5-year Impact Factor & Category & Rank in Category & Quartile in Category & Number of Articles \\
\hline Group Decision and Negotiation & 1.869 & 1.698 & $\begin{array}{l}\text { Management; Social } \\
\text { Sciences, } \\
\text { Interdisciplinary }\end{array}$ & $105 / 210,20 / 98$ & Q2, Q1 & 1 \\
\hline Information Systems Management & 1.255 & 2.025 & $\begin{array}{l}\text { Computer Science, } \\
\text { Information Systems }\end{array}$ & $100 / 148$ & Q3 & 1 \\
\hline $\begin{array}{l}\text { International Entrepreneurship and } \\
\text { Management Journal }\end{array}$ & 2.406 & 2.469 & $\begin{array}{c}\text { Business, } \\
\text { Management }\end{array}$ & $67 / 140,80 / 210$ & Q2 & 1 \\
\hline $\begin{array}{l}\text { International Journal of } \\
\text { Management Reviews }\end{array}$ & 6.489 & 8.941 & $\begin{array}{c}\text { Business, } \\
\text { Management } \\
\text { Management; }\end{array}$ & $8 / 140,5 / 210$ & Q1 & 1 \\
\hline $\begin{array}{c}\text { International Journal of Technology } \\
\text { Management }\end{array}$ & 0.869 & 1.556 & $\begin{array}{l}\text { Operations Research } \\
\text { \& Management } \\
\text { Science }\end{array}$ & $183 / 210,69 / 84$ & Q4, Q4 & 1 \\
\hline Journal of Business Venturing & 6 & 9.069 & Business & $10 / 140$ & Q1 & 1 \\
\hline Journal of Economic Surveys & 2.299 & 3.54 & Economics & $61 / 353$ & Q1 & 1 \\
\hline Management International Review & 2.279 & 2.752 & Management & $86 / 210$ & Q2 & 1 \\
\hline Marketing Intelligence \& Planning & 1.421 & - & Business & $97 / 140$ & Q3 & 1 \\
\hline Accounting Review & 0.886 & - & Business, Finance & $68 / 98$ & Q3 & 1 \\
\hline Strategic Entrepreneurship Journal & 3.488 & 4.291 & $\begin{array}{c}\text { Business, } \\
\text { Management } \\
\text { Operations Research }\end{array}$ & $34 / 140,43 / 210$ & Q1 & 1 \\
\hline Technovation & 4.802 & 5.407 & $\begin{array}{l}\text { \& Management } \\
\text { Science }\end{array}$ & $2 / 84$ & Q1 & 1 \\
\hline
\end{tabular}




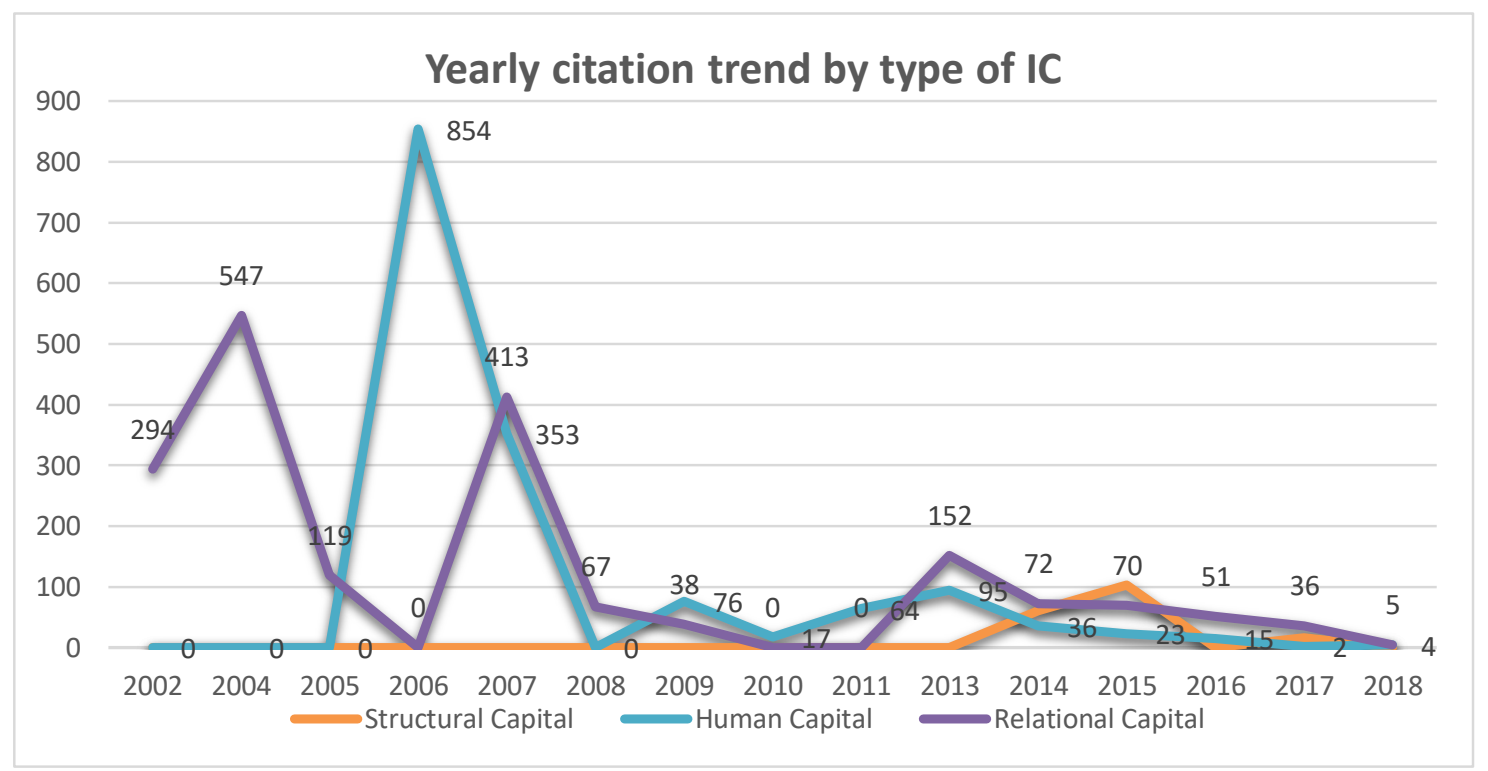

Figure 3. The yearly citation trend by type of intellectual capital.

Via performing the analysis of the yearly citation trend by type of intellectual capital in relation to the SMEs internationalization, several aspects are worth considering. On the one hand, as illustrated above, over the years, the contributions focused on the role of human capital have gathered the highest number of citations, being followed by the ones revolving around the role of relational capital. On the other hand, the interest in the role of structural capital has sprung in 2013, reaching a peak in 2015. Over the past three years, the papers concentrated on relational capital have gathered the highest number of citations, thus confirming a keen research interest in this area and calling for further investigations through the lens of the other types of IC, that is human and structural.

\subsection{Research Directions Bridging Intellectual Capital and SMEs Internationalization}

When talking about internationalization of SMEs, Alon et al. [55] reveal several key dimensions: (a) intellectual and social capital, (b) entrepreneurial proclivity (fear of failure, perception of opportunities, and opportunity-driven motivations), (c) uniqueness of offerings/innovativeness, (d) and scale of new business. Among the motivations associated with internationalization initiatives, the literature in the field lists the economies of scale, knowledge acquisition and leverage, market power enhancement, stronger capabilities achievement, multilevel innovation, entrepreneurial opportunities seeking, sustainable competitive advantage, etc. $[11,12,16,17,22,23,126,127]$. Adjectively, the factors that influence the managerial decision to internationalize are related to knowledge of foreign languages, understanding of business opportunities, saturation on the local market, increased competition, globalization trend, and international contacts [36] (p. 53).

In this vein, the intellectual capital covers skills, capabilities and acquired knowledge [10] (p. 245), comprising a set of assets which assist the achievement of sustainable business objectives [118]. In this vein, the intellectual capital covers skills, capabilities and acquired knowledge [10] (p. 245), comprising a set of assets which assist the achievement of sustainable business objectives [128]. Consistent with $\mathrm{Xu}$ and Wang [129], IC should be deemed as a wealth generator with a great potential to engender competitive advantage and sustainability in business. Their findings concluded that IC had a positive impact on companies' sustainable growth, thus extending the "understanding of IC in creating corporate value and building sustainable advantages in emerging economies" (p. 1).

Further, Zucchella, Palamara and Denicoali [130] (p. 45) propose a different standpoint on the scope of the intellectual capital, perceiving it as an interactional process with a strong managerial and entrepreneurial imprint. The human capital is the driving force of the creation of new assets oriented towards and required by other markets [7], while the structural capital 
elements (i.e., business strategies and processes) are crucial to leveraging previous experience and knowledge [22]. The internal (structural) resources of a SME are very specific and propel the creation of sustainable value for the company, thus they should be properly exploited and applied through coherent endeavors [9]. The relational capital adds to the extant framework the inherent bonding infrastructure as it encompasses the enterprise's networks formed by employees, customers, suppliers, and distributers [44]. Here, while human capital relates to human skills, experience, know-how, competences and knowledge [3], relational capital primarily refers to outside connections, customer relationships, investor relationships [22,23,44].

Focusing on the human capital dimension, empirical research has already confirmed that human capital positively moderates the relationship between internationalization and firm performance [13,29] whereas key success factors of SMEs internationalization are often linked to the skills and knowledge of human resources [36]. In this context, positive relationships were supported between human capital and the firm's level of internationalization $[1,13,111]$.

Molodchik, Shakina and Bykova [2] contend that that human capital becomes relevant in the long-term scenarios if linked to highly-educated managers who are capable of creating sustainable business value via the capitalization of strategies, innovation behavior, and social networks [9]. In this sense, Chen posits that the educational level of managers is positively associated with the business internationalization success. This may be a facilitator for a more efficient decision-making process which catalyzes a better resolution on organizational challenges [6] and sustainability [14].

Going further, managers' international experience contributes to their international orientation $[5,12,29,46,77]$, therefore, forming the basis for the internationalization of SMEs [2,13]. In the developing countries, managers who were able to use their capabilities in the quest for sustainable business opportunities, locally and afterwards internationally, once they establish the right course of action for resources exploitation, they succeeded in exploring and taking advantage of market opportunities [22,84]. Likewise, the entrepreneurial international orientation involves the perceptions regarding the benefits and the costs of the internationalization and the business experience along with international exposure develop mechanisms to enter foreign markets [84,131]. A manager with creative capacity, who studied or worked in foreign countries, has the ability to easily connect across countries or different markets [55] and to better identify opportunities towards building sustainable business collaborations [131].

Internationalization provides a chance for experienced managers to demonstrate their skills, and by knowing foreign markets and other external challenges they are capable to overlap difficulties and to grow SMEs' international acquisitions [29]. Internationalization activities (export and the relocation of production activities) determine the need for new competences such as managerial capabilities, language skills, foreign market knowledge [82]. Nevertheless, the knowledge of foreign market can be balanced by product development, price differentiation, technological innovation, and the stage of the internationalization [84].

Moving forward to the structural capital dimension, it should be underlined that it contains all the non-human pieces of knowledge available within the organization, including here the databases, strategies, regulations, and routines, anything whose value to the company is higher than its material value [132] (p. 92). Information restriction inhibits individual learning, affecting the internal communication setup, thereby inhibiting collective learning. Intra-organizational cognitive elements promote collective systems [133], which may later impede the international expansion of SMEs.

In this front, the international business literature is in an incipient phase in correlating the structural capital and SMEs internationalization. There are some studies referring to the dynamic capabilities which assist SMEs to better handle organizational resources so as to surpass market obstacles [19]. Ozdemir [44] considers that high-quality products/services and professional competence (foreign language and knowledge of export procedures) stand for important intellectual capital factors, subsequently linked to the structural capital. In the absence of such assets, the internationalization process is likely to fail. 
Similarly, Maditinos, Šević and Tsairidis [20] affirm that once enterprises properly use the organizational body of knowledge, they will gain a sustainable competitive edge which will later result in business performance. A pertinent usage of the structural capital would ensure the formation of knowledge-intensive groups performing higher tasks $[4,26]$. In this manner, structural capital is also presumed to positively influence business performance.

Laying emphasis on the relational capital component, various researches have upheld that SMEs competitiveness is enhanced by intangible resources and that it is crucial for enterprises to acknowledge the importance of collaboration [18]. Lu and Beamish [127] reveal that intangible resources augment the value of international activities, providing positive effects on the geographical expansion and performance at all levels of internationalization.

The relational capital consists of established relationships with different business groups, other firms, entrepreneurs, clients, stakeholders and even foreign institutions. Relational capital covers three dimensions of a partnership: trust leading to information sharing, knowledge and problem solving [133]. The relational capital is a strategic asset for SMEs in the pursuit of sustainable competitive advantage and it is a dimension of social capital [50]. Social capital represents per se a resource for SMEs and might be defined as the formation of social relationships which bring benefits [8]. Building social capital in business relationships relates also to actors who possess financial resources, political contacts, and access to knowledge and information $[8,111]$. In the relational context of SMEs, strategic alliances are a different approach to surpass the lack of resources and to potentiate intellectual capital, changing the organizational performance of the firm in a positive way [18]. The involvement of SMEs in different strategic alliances enhances the entrepreneurial orientation towards sustainable international ventures. The capabilities and behavior of an entrepreneur, his education and learning capacity convey a different perspective about the need to engage in business abroad. As Ruzzier, Antoncic, Hisrich and Konecnik [46] reveal, the firm's internationalization cannot unfold successfully without the convergence of the four dimensions of human capital: international orientation, risk perception, business skills, and management know-how.

The affiliation of SMEs to business networks is often very important for their survival on foreign markets, the development of such relations accounting for the success of internationalization-partners from different countries and with different cultural backgrounds and management characteristics are liable to work together to overcome market challenges and obstacles in a sustainable way [119]. Moreover, the empirical findings of Hitt, Bierman, Uhlenbruck and Shimizu [13] show that the relational capital based on relationships with foreign governments has a strong, positive effect on internationalization, but a negative effect on firm performance. SMEs' capacity to access institutional benefits depends on both individual and organizational factors, establishing relations with chambers of commerce providing another worthy channel [19].

When corroborating human, structural and relational capital, the enterprises with a larger web of contacts, more resources and managerial know-how are more likely to internationalize [55]. At the same time, firms with founders acquiring and storing more industry-specific knowledge and managing specialized employees are more likely to grow internationally [45].

Going further, after examining factors that drive internationalization undertakings, Vedula and Matusik [77] conclude that the initial experiences, the role of social cues, and firm-level heterogeneity are definitive in this dynamic. Individual relationships within a firm or with customers, contact networks involve social interaction and knowledge transfer and it represents a learning process, with the real capacity to strengthen business transactions $[12,50]$. The social cues have a major role in the managerial decisions whereas similarities with other firms influence actions; even though a firm possesses its own knowledge and routines, the common experiences will settle different capabilities and routines over time [77].

Narrowing down the analysis to family-owned SMEs, Fernández-Olmos, Gargallo-Castel and Giner-Bagües [70], as well as Scholes, Mustafa and Chen [100] assert that these firms are usually not prepared for the international market as they lack financial resources, management capabilities 
and are reluctant to international networks. The lack of international strategies results in failure to internationalize and to obtain performance $[6,18,70,73,84]$.

The manager who usually supports internationalization in a family-owned SME is often a non-family member who primarily concentrates his efforts towards operational goals and less to strategic/sustainable ones [51]. A non-family manager who fully understands and acknowledges the benefits of internationalization is not influenced by family obligations and is likely to potentiate foreign business initiatives and horizontal connections, building trust externally, helping the family-owned SMEs to succeed internationally $[51,118]$.

As a corollary of the interaction between the three dimensions of the intellectual capital in the specific case of family-owned SMEs internationalization, various studies [51,71,92,119] posit that the rightly-equipped managers have the ability to harvest and enhance the organizational resources and translate them into articulate and sustainable international strategies via a proper capitalization of external collaborations and partnerships. Once the family businesses reach a higher degree of internationalization, they spread their reputation, build external networks, and ultimately accumulate capabilities that ensure a good position on the market $[70,72,74]$, thus yielding internationalization benefits by means of different intellectual capital dimensions.

\section{Discussion and Conclusions}

\subsection{Summary of the Main Findings and Future Research Avenues}

The analysis of the selected papers relevant for the correlation between the intellectual capital dimensions and SMEs internationalization through the lens of sustainable competitive advantage brought to the fore several key findings both in terms of methodological design and content.

Firstly, it has become obvious that conceptual papers in the field are scarce despite the variety of their aims and approaches. Here, the extant systematic literature reviews in the field have not thoroughly discussed the relationships among the construct triad (i.e., intellectual capital-SMEs internationalization-sustainable competitive advantage) and they have not explicitly mainstreamed the state of the field as their search goals revolved around different correlations-i.e., human capital development and SME internationalization in the CEE region [12], SME innovation, exporting and growth [83], internationalizing in the transition economies of Central and Eastern Europe [105]. All these systematic approaches have put forward compelling insights for the scope of the current endeavor, nevertheless they only set the premises for a more targeted outlook of the key variables. Given the fact that our search strategy did not return breakthrough approaches on the topic and in light of the findings of previous studies [30-35], we acknowledged the existence of a research gap and the imperative to provide an output for readers and researchers (i.e., a research agenda and/or a conceptual framework on the topic) liable to bring to the fore future research avenues.

To a certain extent, the same applies to the empirical papers. The analyzed articles underscored that the quantitative-based empirical studies prevail over the qualitative ones, while mixed methods research designs are scant. Going beyond the methodological designs, none of the identified papers comprises all the concepts of the triad in their titles or abstracts, a confirmation in this front residing in the employed searched strategy which did not retrieve any results when selecting the title and abstract as tag fields. This situation is indicative of the fact that these studies have not discussed the relationships among the constructs/key variables in a comprehensive framework, but rather in tangential approaches, thus calling for more articulate and specific investigations. A new path towards further exploration of the underlying conceptual relationships between constructs and of the structural relationships between factors within more complex methodological designs is opened, all the more so as, nowadays, SMEs internationalization process cannot be framed anymore in the absence of intangible assets and sustainability views [14-19,30-35,129]. Moreover, taking into consideration the distribution criterion of articles with regard to the year of publication and the source journals most contributions have been published in (as depicted in Table 3), a growing interest has been displayed 
in academia and research for this topic or for related ones since 2011, as objectivized in top-ranked scientific outlets.

Secondly, the literature review revealed that most of the research samples investigated in the empirical studies come from European countries, e.g., [32,84,105,121], thus are context-driven. Even though this fact may be considered as a propelling factor for an articulate phenomenological view on the internationalization process of European SMEs, an extension of the research area is worth considering with a view to generalize the evidence stemmed from country-specific analyses. A multi-setting overview would ensure the identification of similarities and differences among national and cultural variables and therefore better assess their various effects in the tested relationships.

Thirdly, a specific categorization of the selected papers was performed according to the dimension of the intellectual capital and the SMEs internationalization model and/or characteristics (see Tables 1 and 2), followed by a corroboration of the two in the other sections. Some studies have been mentioned in more categories as they tackled more issues or they had assumed multifold aims. In this front, future literature reviews on the topic may consider providing a more in-depth approach on the relationship between the three constructs so that the explored references are classified according to additional criteria (e.g., research purpose, objectives, hypotheses, questions, techniques, samples, etc.). By corroborating the current findings with further information regarding the actual content of the research designs, new matrices may emerge and trace the underlying links among different units, thus offering a consistent nomological network for the investigations in the field.

Additionally, the analysis of the yearly citation trend by type of intellectual capital in relation to the SMEs internationalization (as depicted in Table 3) brought forward that prior studies laid emphasis on the role of human capital (in terms of number of citations), being followed by the role of relational capital. The relevance of the structural capital has been confirmed more recently via an increase in the number of citing papers. In this point, the managerial strategies and practices along with other organizational intangible resources have been credited with added value in SMEs internationalization in their quest for sustainable competitive advantage, implicitly paving the way for new research trends capturing today's inter-firm dynamics, e.g., [98-101].

Fourthly, somehow related to the aforementioned point, the conducted literature review was concept-centric, thus constructs being the ones to determine the organizing framework of the review. At this level, further systematic undertakings could envisage a transition from concept to author-centric or to joint approaches, offering the opportunity for more detailed categorizations based on articulate schemes defining the multidisciplinary nature of the topic area. A pertinent endeavor in this regard may be a reconfiguration of the search strategy as to entail the application of BGC bibliometric methods that identify clusters of publications relevant for a set of pre-defined criteria meant to round off the view on the underlying relationships among various units/levels of analysis. The author-centric perspective is liable to offer further insights into data concerning the most productive authors, and a potential collaboration index (i.e., constant versus episodic collaborations among the same authors, the dedication of certain authors to the study of a certain research stream, topic, relationships).

Fifthly, most of the investigated studies have not explicitly referred to a certain type of intellectual capital-they have not employed the constructs as such, but defined and operationalized them according to other theoretical frameworks or paradigms. Concurrently, a myriad of studies does not explicitly refer to a classical internationalization model or to a specific sustainability perspective and are rather ambiguous in terms of the internationalization phases. This situation brings forward a research gap in that future studies may consider better placing the straightforward construct of intellectual capital within the research streams of the international business literature. More thorough insights into the link between the influence of certain dimensions of intellectual capital on specific internationalization phases or strategies are also welcomed in order to round off the frame of reference. 


\subsection{Originality and Limitations}

On the one hand, to the best of our knowledge, this is among the first systematic literature reviews conducted on the various relationships between intellectual capital and SMEs internationalization in the quest for achieving sustainable competitive advantage. In this respect, the argumentative discourse aimed at approaching the conceptual triad in an integrative framework, setting the premises for a novel theoretical understanding of the relationships among key variables and simultaneously calling for further examinations liable to bring together previously-disparate research streams. Placed within an interdisciplinary framework straddling several disciplines (i.e., business, management, entrepreneurship, economics, etc.), the concept-centric review is expected to provide a conceptual chart to scholars interested to pursue similar research directions, to pinpoint the extant knowledge gaps and to catalyze their interest to close the multifaceted breaches.

On the other hand, the timespan of the analysis covers 18 years, giving credit to both seminal contributions and recent developments in the field. However, the selected papers for performing the literature review only comprised scientific articles published in peer-reviewed journals in the field of international business, management and entrepreneurship which were identified via the exploration of Clarivate Analytics, EBSCO, Science Direct databases as search engines. Two issues emerge here. Firstly, the search strategy was limited to an exclusive focus on the results retrieved by the three online databases, and it did not employ the citation method (e.g., cross-search) as a validation criterion in this point. This avails the opportunity to conduct further systematic reviews more objectively, by identifying and retrieving relevant papers cited in the body literature, but not initially selected by means of the selected databases and search terms. Secondly, other sources-i.e., conference papers, chapters, books, etc.- - were not considered, thus, the provided outlook is dependent on a certain type of publications. In order to overcome this limitation, further similar undertakings would benefit from extending the selection parameters to additional relevant references which may enrich the research streams and key findings in the field. The consideration of other relevant online databases for the social sciences domain (e.g., Scopus, ProQuest) and of the conference proceedings "with a reputation for quality" as Webster and Watson [57] posited, would meet some of these concerns.

Author Contributions: Conceptualization, E.M.V. and E.A.G.; methodology, M.P. and A.M.G.; formal analysis, E.M.V. and E.A.G.; investigation, E.M.V.; resources, E.A.G.; data curation, A.M.G. and M.P.; writing-original draft preparation, E.A.G.; writing-review and editing, E.M.V.

Funding: This work was supported by a grant from the Ministry of Research and Innovation, CNCS-UEFISCDI, project number PN-III-P1-1.1-TE-2016-0232, within PNCDI III.

Conflicts of Interest: The authors declare no conflict of interest.

\section{References}

1. Cerrato, D.; Piva, M. The internationalization of small and medium-sized enterprises: The effect of family management, human capital and foreign ownership. J. Manag. Gov. 2012, 16, 617-644. [CrossRef]

2. Chen, H.-L. Independent directors' human capital and firm internationalization. Asian Econ. Fin. Rev. 2014, 4, 1378-1388.

3. Choong, K.K. Intellectual capital: Definitions, categorization and reporting models. J. Intell. Cap. 2008, 9, 609-638. [CrossRef]

4. Fujita, M.; Hamaguchi, N. Supply chain internationalization in East Asia: Inclusiveness and risks. Pap. Reg. Sci. 2016, 95, 81-100. [CrossRef]

5. Herrmann, P.; Datta, D.K. Relationships between top management team characteristics and international diversification: An empirical investigation. Br. J. Manag. 2005, 16, 69-78. [CrossRef]

6. Kok, A. Intellectual Capital Management as Part of Knowledge Management Initiatives at Institutions of Higher Learning. Electron. J. Knowl. Manag. 2007, 5, 181-192.

7. Alarcon Osuna, A.; Fong Reynoso, C.; Ocampo Figueroa, L.E. The effects of internationalization, intangible resources and technological change on the transition to a multiproduct company: Evidence of the Mexican case. Pensam. Gestión 2017, 42, 48-72. [CrossRef] 
8. Braga Rodrigues, S.; Child, J. Building Social Capital for Internationalization. Revista de Administração Contemporânea 2012, 16, 23-38. [CrossRef]

9. Molodchik, M.A.; Shakina, E.A.; Bykova, A.A. Intellectual Capital Transformation Evaluating Model. J. Intell. Cap. 2012, 13, 444-461. [CrossRef]

10. Nahapiet, J.; Ghoshal, S. Social Capital, Intellectual Capital, and the Organizational Advantage. Acad. Manag. Rev. 1998, 23, 242-266. [CrossRef]

11. Chen, H.-L.; Chang, C.-Y.; Hsu, W.-T. Does Board Co-Working Experience Influence Directors' Decisions Toward Internationalization? Manag. Int. Rev. 2017, 57, 65-92. [CrossRef]

12. Gittins, T.; Fink, M. Return migration, informal learning, human capital development and SME internationalization in the CEE region: A systematic literature review. J. East Eur. Manag. Stud. 2015, 20, 279-303. [CrossRef]

13. Hitt, M.A.; Bierman, L.; Uhlenbruck, K.; Shimizu, K. The importance of resources in the internationalization of professional service firms: The good, the bad, and the ugly. Acad. Manag. J. 2006, 49, 1137-1157. [CrossRef]

14. Păduraru, T.; Vătămănescu, E.-M.; Andrei, A.G.; Pînzaru, F.; Zbuchea, A.; Maha, L.G.; Boldureanu, G. Sustainability in Relationship Marketing: An Exploratory Model for the Industrial Field. Environ. Eng. Manag. J. 2016, 15, 1635-1647. [CrossRef]

15. Vătămănescu, E.-M.; Alexandru, V.-A.; Gorgos, E.-A. The Five Cs Model of Business Internationalization (CMBI) - A preliminary theoretical insight into today's business internationalization challenges. In Strategica. Management, Finance, and Ethics; Brătianu, C., Zbuchea, A., Pînzaru, F., Vătămănescu, E.-M., Eds.; Tritonic: Bucharest, Romania, 2014; pp. 537-558.

16. Vătămănescu, E.-M.; Zbuchea, A.; Pînzaru, F.; Andrei, A.G. The Impact of Relational Capital on SMEs Internationalization. Leveraging Online Versus Offline Business Networking. In Proceedings of the 17th European Conference on Knowledge Management; Moffett, S., Galbraith, B., Eds.; Academic Conferences and Publishing International Limited: London, UK, 2016; pp. 926-935.

17. Vătămănescu, E.-M.; Alexandru, V.-A.; Treapăt, L.-M. A five Dimension Framework for International Business Relationships the B2B Approach. In Proceedings of the 28th International Business Information Management Association Conference. Vision 2020: Innovation Management, Development Sustainability, and Competitive Economic Growth; Soliman, K.S., Ed.; International Business Information Management Association: Norristown, PA, USA, 2016; pp. 385-395.

18. Ferreira, A.; Franco, M. The Mediating Effect of Intellectual Capital in the Relationship between Strategic Alliances and Organizational Performance in Portuguese Technology-Based SMEs. Eur. Manag. Rev. 2017, 14, 303-318. [CrossRef]

19. Landau, C.; Karna, A.; Richter, A.; Uhlenbruck, K. Institutional leverage capability: Creating and using institutional advantages for internationalization. Glob. Strateg. J. 2016, 6, 50-68. [CrossRef]

20. Maditinos, D.; Šević, Z.; Tsairidis, C. Intellectual Capital and Business Performance: An Empirical study for the Greek Listed Companies. In Proceedings of the 7th International Conference on Accounting and Finance in Transition (ICAFT), London, UK, 23-25 July 2009.

21. Swoboda, B.; Berg, B.; Dabija, D.C. International Transfer and Perception of Retail Formats: A comparison Study in Germany and Romania. Int. Mark. Rev. 2014, 31, 155-180. [CrossRef]

22. Vătămănescu, E.-M.; Andrei, A.G.; Nicolescu, L.; Pînzaru, F.; Zbuchea, A. The Influence of Competitiveness on SMEs Internationalization Effectiveness. Online versus Offline Business Networking. Inf. Sys. Manag. 2017, 34, 205-219. [CrossRef]

23. Vătămănescu, E.-M.; Alexandru, V.-A.; Nistoreanu, B.G. Leveraging Business Relationships as SMEs Internationalization Drivers. In BASIQ International Conference: New Trends in Sustainable Business and Consumption 2017; Pamfilie, R., Dinu, V., Tăchiciu, L., Pleșea, D., Vasiliu, C., Eds.; ASE: Bucharest, Rpmania, 2017; pp. 733-741.

24. Basly, S. The internationalization of family SME: An organizational learning and knowledge development perspective. Balt. J. Manag. 2007, 2, 154-180. [CrossRef]

25. Gruenhagen, J.H.; Sawang, S.; Gordon, S.R.; Davidsson, P. International experience, growth aspirations and the internationalization of new ventures. J. Int. Entrep. 2018, 16, 421-440. [CrossRef]

26. Javalgi, R.G.; Grossman, D.A. Firm Resources and Host-Country Factors Impacting Internationalization of Knowledge-Intensive Service Firms. Thunderbird Int. Bus. Rev. 2014, 56, 285-300. [CrossRef] 
27. Onkelinx, J.; Manolova, T.S.; Edelman, L.F. The role of employee human capital in the accelerated internationalization of SMEs. Front. Entrep. Res. 2012, 32, 1.

28. Pelău, C.; Bena, I.; Vlădoi, A.D.; Dabija, D.C.; Fufezan, M. The Quality of Knowledge Flows and its Impact on the Intellectual Capital Development of a University. In Proceedings of the 3rd European Conference on Intellectual Capital; Turner, G., Minnone, C., Eds.; Academic Publishing International Limited: Nicosia, Cyprus, 2011; pp. 322-327.

29. Volonte, C.; Gantenbein, P. Directors' human capital, firm strategy, and firm performance. J. Manag. Gov. 2016, 20, 115-145. [CrossRef]

30. Cohen, S.; Kaimenakis, N. Intellectual capital and corporate performance in knowledge-intensive SMEs. Learn. Org. 2007, 14, 241-262. [CrossRef]

31. Korsakienè, R.; Liučvaitienè, A.; Bužavaitè, M.; Šimelytè, A. Intellectual capital as a driving force of internationalization: A case of Lithuanian SMEs. Int. J. Entrep. Sustain. Issues 2017, 4, 502-515. [CrossRef]

32. Jaakkola, M.; Moller, K.; Parvinen, P.; Evanshitzky, H.; Muhlbacher, H. Strategic marketing and business performance: A study in three European engineering countries. Ind. Market. Manag. 2010, 39, 1300-1310. [CrossRef]

33. Na, Y.K.; Kang, S.; Jeong, H.Y. The Effect of Market Orientation on Performance of Sharing Economy Business: Focusing on Marketing Innovation and Sustainable Competitive Advantage. Sustainability 2019, 11, 729. [CrossRef]

34. Ying, Q.; Hassan, H.; Ahmad, H. The Role of a Manager's Intangible Capabilities in Resource Acquisition and Sustainable Competitive Performance. Sustainability 2019, 11, 527. [CrossRef]

35. Januškaitè, V.; Užienè, L. Intellectual Capital as a Factor of Sustainable Regional Competitiveness. Sustainability 2018, 10, 4848. [CrossRef]

36. Bilas, V.; Franc, S.; Kvaternjak, I. Internationalization of micro and small enterprises in the information technology industry of the Republic of Croatia. Econ. Rev. J. Econ. Bus. 2013, 11, 45-59.

37. Vătămănescu, E.-M.; Andrei, A.-G.; Leovaridis, C.; Dumitriu, L.-D. Exploring network-based intellectual capital as a competitive advantage. An insight into European universities from developing economies. In Proceedings of the 7th European Conference on Intellectual Capital ECIC 2015; Cegarra Navarro, J.G., Ed.; Academic Conferences and Publishing International Limited: London, UK, 2015; pp. 350-358.

38. Vătămănescu, E.-M.; Andrei, A.G.; Dumitriu, D.-L.; Leovaridis, C. Harnessing network-based intellectual capital in online academic networks. From the organizational policies and practices towards competitiveness. J. Knowl. Manag. 2016, 20, 594-619. [CrossRef]

39. Bratianu, C. Intellectual capital research and practice: 7 myths and one golden rule. Manag. Mark. Chall. Knowl. Soc. 2018, 13, 859-879. [CrossRef]

40. Dean, A.; Kretschmer, M. Can ideas be capital? Factors of production in the postindustrial economy: A review and critique. Acad. Manag. Rev. 2007, 32, 573-594. [CrossRef]

41. Leitner, K.H.; Perez, S.E.; Fazlagic, J.; Kalemis, K.; Martinaitis, Z.; Secundo, G.; Sicilia, M.A.; Zaksa, K. A Strategic Approach for Intellectual Capital Management in European Universities, Guidelines for Implementation; Final Report; UEFISCDI Blueprint Series: Bucharest, Romania, 2014; Available online: http://aer.forhe.ro/ sites/default/files/blueprint_ic_management_in_universities.pdf (accessed on 7 January 2019).

42. Johanson, J.; Vahlne, J.E. The mechanism of internationalization. Int. Mark. Rev. 1990, 7, 11-24. [CrossRef]

43. Nordman, E.R.; Tolstoy, D. The impact of opportunity connectedness on innovation in SMEs' foreign-market relationships. Technovation 2016, 57-58, 47-57. [CrossRef]

44. Ozdemir, N. Intellectual Capital Management in the Context of Internationalization. In 9th European Conference on Intellectual Capital; Lopes, I.T., Serrasqueiro, R., Eds.; Curran Associates, Inc.: Lisbon, Portugal, 2017; pp. 367-375.

45. Sapienza, H.J.; Autio, E.; George, G.; Zahra, S.A. A capabilities perspective on the effects of early internationalization on firm survival and growth. Acad. Manag. Rev. 2006, 31, 914-933. [CrossRef]

46. Ruzzier, M.; Antoncic, B.; Hisrich, R.D.; Konecnik, M. Human Capital and SME Internationalization: A Structural Equation Modeling Study. Can. J. Adm. Sci. 2007, 24, 15-29. [CrossRef]

47. Ajayi, B. The impact of entrepreneurial orientation and networking capabilities on the export performance of Nigerian Agricultural SMEs. J. Entrep. Innov. Emerg. Econ. 2016, 2, 1-23. [CrossRef]

48. D'Angelo, A.; Majocchi, A.; Zucchella, A.; Buck, T. Geographical pathways for SME internationalization: Insights from an Italian sample. Int. Mark. Rev. 2013, 30, 80-105. [CrossRef] 
49. Giovannetti, G.; Marvasi, E.; Sanfilippo, M. Supply Chains and the Internalization of SMEs: Evidence from Italy, Research Paper No. RSCAS 2014/62. Robert Schuman Centre for Advanced Studies. 2014. Available online: https://papers.ssrn.com/sol3/papers.cfm?abstract_id=2441121 (accessed on 16 January 2019).

50. Li, C.-L.; Channg, W.; Hsieh, J. The Importance of Social Capital to the Management of Multinational Firms: Relational Networks among Chinese and American Firms. In Proceedings of the European Conference on Intellectual Capital; Rodrigues, S.C.S.F., Ed.; Academic Conferences: Reading, UK, 2010; pp. 374-382.

51. Bika, Z.; Kalantaridis, C. Organizational-Social-Capital, Time and International Family SMEs: An Empirical Study from the East of England. Eur. Manag. Rev. 2017. [CrossRef]

52. Gabrielsson, J.; Winlund, H. Boards of directors in small and medium-sized industrial firms: Examining the effects of the board's working style on board task performance. Entrep. Reg. Dev. 2000, 12, 311-330. [CrossRef]

53. Ribau, C.P.; Carrizo Moreira, A.; Raposo, M. SME internationalization research: Mapping the state of the art. Can. J. Adm. Sci. 2018, 35, 280-303. [CrossRef]

54. Soler, I.P.; Gemar, G.; Guerrero-Murillo, R. Family and non-family business behaviour in the wine sector: A comparative study. Eur. J. Fam. Bus. 2017, 7, 65-73. [CrossRef]

55. Alon, I.; Yeheskel, O.; Lerner, M.; Zhang, W. Internationalization of Chinese Entrepreneurial Firms. Thunderbird Int. Bus. Rev. 2013, 55, 495-512. [CrossRef]

56. Vahlne, J.-E.; Johanson, J. The Uppsala model on evolution of the multinational business enterprise-From internationalization to coordination of networks. Int. Mark. Rev. 2013, 30, 189-210. [CrossRef]

57. Webster, J.; Watson, R.T. Analyzing the Past to Prepare for the Future: Writing a Literature Review. MIS Q. 2002, 26, xiii.

58. Li, K.; Rollins, J.; Yan, E. Web of Science use in published research and review papers 1997-2017: A selective, dynamic, cross-domain, content-based analysis. Scientometrics 2018, 115, 1-20. [CrossRef]

59. King's College London. Searching for Systematic Reviews: Searching Databases. 2019. Available online: http://libguides.kcl.ac.uk/systematicreview/searchdb?fbclid= IwAR230coNPbrvnAhEJ8qvaye1K4qQ4B4F3R9Qw0Hzt7SrkoflWhN4Zy6s5AE (accessed on 30 March 2019).

60. EBSCO. Business Source. The Essential Research Database for Peer-Reviewed, Full-Text Business Journals. 2019. Available online: https://www.ebsco.com/products/research-databases/business-source (accessed on 30 March 2019).

61. ScienceDirect. Fact Sheet. 2019. Available online: https://p.widencdn.net/ssgnu1/ACAD_LIB_SD_FS_ genericfactsheet_WEB (accessed on 30 March 2019).

62. Petty, P.; Guthrie, J. Intellectual Capital Literature Review: Measurement, Reporting and Management. J. Int. Cap. 2000, 2, 155-175. [CrossRef]

63. Al-Laham, A.; Souitaris, V. Network embeddedness and new venture internationalization: Analyzing international linkages in the German biotech industry. J. Bus. Ventur. 2008, 23, 567-586. [CrossRef]

64. Brouthers, K.D.; Nakos, G.; Dimitratos, P. SME Entrepreneurial Orientation, International Performance, and the Moderating Role of Strategic Alliances. Entrep. Theory Pract. 2015, 39, 1161-1187. [CrossRef]

65. Gilmore, A.; Carson, D.; Grant, K. SME marketing in practice. Mark. Intell. Plan. 2001, 19, 6-11. [CrossRef]

66. Musteen, M.; Datta, D.K.; Butts, M.M. Do international networks and foreign market knowledge facilitate SME internationalization? Evidence from the Czech Republic. Entrep. Theory Pract. 2014, 38, 749-774. [CrossRef]

67. Kungwansupaphan, C.; Siengthai, S. Exploring entrepreneurs' human capital components and effects on learning orientation in early internationalizing firms. Int. Entrep. Manag. J. 2014, 10, 561-587. [CrossRef]

68. Ismail, M.D.; Domil, A.K.A.; Isa, A. Managerial Competence, Relationship Quality and Competitive Advantage among SME Exporters. Procedia Soc. Behav. Sci. 2014, 115, 138-146. [CrossRef]

69. Odlin, D.; Rea, B.M. Competing on the edge: Implications of network position for internationalizing small and medium-sized enterprises. Int. Bus. Rev. 2017, 24, 736-748. [CrossRef]

70. Fernández-Olmos, M.; Gargallo-Castel, A.; Giner-Bagües, E. Internationalisation and performance in Spanish family SMEs: The W-curve. Bus. Res. Q. 2016, 19, 122-136. [CrossRef]

71. Cano-Rubio, M.; Fuentes-Lombardo, G.; Vallejo-Martos, M.C. Influence of the lack of a standard definition of family business on research into their international strategies. Eur. Res. Manag. Bus. Econ. 2017, 23, 132-146. [CrossRef] 
72. D'Angelo, A.; Majocchi, A.; Buck, T. External managers, family ownership and the scope of SME internationalization. J. World Bus. 2016, 51, 534-547. [CrossRef]

73. Graves, C.; Shan, Y.G. An Empirical Analysis of the Effect of Internationalization on the Performance of Unlisted Family and Nonfamily Firms in Australia. Fam. Bus. Rev. 2014, 27, 142-160. [CrossRef]

74. Merino, F.; Monreal-Pérez, J.; Sánchez-Marín, G. Family SMEs' internationalization: Disentangling the influence of familiness on Spanish firms' export activity. J. Small Bus. Manag. 2015, 53, 1164-1184. [CrossRef]

75. Bialek-Jaworska, A.; Gabryelczyk, R. Biotech spin-off business models for the internationalization strategy. Balt. J. Manag. 2016, 11, 380-404. [CrossRef]

76. Galati, A.; Crescimanno, M.; Rossi, M.; Farruggia, D.; Tinervia, S. The determinants affecting the internationalization of the Italian SMEs producing sparkling wines: An empirical study on the RBV of the firms. Int. J. Glob. Small Bus. 2014, 6, 100-118. [CrossRef]

77. Vedula, S.; Matusik, S.F. Geographic, Network, and Competitor Social Cues: Evidence from U.S. Venture Capitalists Internationalization Decisions. Strateg. Entrep. J. 2017, 11, 393-421. [CrossRef]

78. Nordman, E.R.; Tolstoy, D. Does relationship psychic distance matter for the learning processes of internationalizing SMEs? Int. Bus. Rev. 2014, 23, 30-37. [CrossRef]

79. Vaugh, A.; Tsagdis, D. Knowledge configurations of small and medium-sized knowledge-intensive firms in a developing economy: A knowledge-based view of business-to-business internationalization. Ind. Mark. Manag. 2018, 71, 160-170.

80. Doornich, J.B. Managerial learning from social capital during internationalization. Int. Bus. Rev. 2018, 27, 877-892. [CrossRef]

81. Figueroa Dorrego, P.; Costa, R.V.; Fernandez, C.F.J. Product Innovation and Relational Capital: Evidence from Portugal. Electron. J. Knowl. Manag. 2013, 11, 295-308.

82. Antonelli, G.; Antonietti, R.; Guidetti, G. Organizational change, skill formation, human capital measurement: evidence from Italian manufacturing firms. J. Econ. Surv. 2010, 24, 206-247. [CrossRef]

83. Love, J.H.; Roper, S. SME innovation, exporting and growth: A review of existing evidence. Int. Small Bus. J. 2015, 3, 28-48. [CrossRef]

84. Nowinski, W.; Rialp, A. Drivers and strategies of international new ventures from a Central European transition economy. J. East Eur. Manag. Stud. 2013, 2, 191-231. [CrossRef]

85. O'Cass, A.; Weerawardena, J. Examining the Role of International Entrepreneurship, Innovation and International Market Performance in SME Internationalization. Eur. J. Mark. 2009, 43, 1325-1348. [CrossRef]

86. San-Martin, S.; Jimenez, N.H.; López-Catalán, B. The firms benefits of mobile CRM from the relationship marketing approach and the TOE model. Span. J. Mark. ESIC 2016, 20, 18-29. [CrossRef]

87. Ayob, A.H.; Ramlee, S.; Rahman, A.A. Financial factors and export behavior of small and medium-sized enterprises in an emerging economy. J. Int. Entrep. 2015, 13, 49-66. [CrossRef]

88. Calabrò, A.; Mussolino, D. How do boards of directors contribute to family SME export intensity? The role of formal and informal governance mechanisms. J. Manag. Gov. 2013, 17, 363-403. [CrossRef]

89. Cancino, C.A. Rapid Internationalization of SMEs: Evidence from Born Global Firms in Chile. Innovar 2014, 24, 141-151. [CrossRef]

90. Goxe, F. Human and social capital interplay among internationalizing SMEs. J. Knowl.-Based Innov. China 2014, 2, 73-88. [CrossRef]

91. Yeoh, P. Internationalization and performance outcomes of entrepreneurial family SMEs: The role of outside CEOs, technology sourcing, and innovation. Thunderbird Int. Bus. Rev. 2014, 56, 77-96. [CrossRef]

92. Colombo, G.; Vătămănescu, E.-M.; Alexandru, V.-A.; Gazzola, P. The influence of internationalization process-based factors on international performance in the case of SMFEs. Econ. Aziend. Online Bus. Manag. Sci. Int. Q. Rev. 2018, 9, 319-332.

93. Eternad, H.; Wright, R.W.; Dana, L.-P. Symbiotic International Business Networks: Collaboration between Small and Large Firms. Thunderbird Int. Bus. Rev. 2001, 43, 481-499.

94. Thurner, T.W.; Gershman, M.; Roud, V. Partnerships as Internationalization strategy: Russian entrepreneurs between local restrictions and global opportunities. J. Int. Entrep. 2015, 13, 118-137. [CrossRef]

95. Badi, S.; Wang, L.; Pryke, S. Relationship marketing in Guanxi networks: A social network analysis study of Chinese construction small and medium-sized enterprises. Ind. Mark. Manag. 2017, 60, 204-218. [CrossRef] 
96. Fajsi, A.; Morača, S. Integrating SMEs into value networks: Benefits and limitations. In Proceedings of the XVII International Scientific Conference on Industrial Systems (IS'17), Novi Sad, Serbia, 4-6 October 2017; Available online: https://www.iim.ftn.uns.ac.rs/is17/papers/48.pdf (accessed on 20 December 2018).

97. Acosta, A.S.; Crespo, H.A.; Agudo, J.C. Effect of market orientation, network capability and entrepreneurial orientation on international performance of small and medium enterprises (SMEs). Int. Bus. Rev. 2018, 27, 1128-1140. [CrossRef]

98. Zhang, X.; Ma, X.; Wang, Y.; Wang, Y. How can emerging market small and medium-sized enterprises maximise internationalization benefits? The moderating effect of organisational flexibility. Int. Small Bus. J. 2014, 32, 667-692. [CrossRef]

99. Pacheco, L. Capital structure and internationalization: The case of Portuguese industrial SMEs. Res. Int. Bus. Financ. 2016, 38, 531-545. [CrossRef]

100. Scholes, L.; Mustafa, M.; Chen, S. Internationalization of small family firms: The influence of family from a socio-emotional wealth perspective. Thunderbird Int. Bus. Rev. 2016, 58, 131-146. [CrossRef]

101. Garcia-Garcia, R.; Garcia-Canal, E.; Guillen, M.F. Rapid internationalization and long-term performance: The knowledge link. J. World Bus. 2017, 52, 97-110. [CrossRef]

102. Zhou, L.; Wu, W.-P.; Luo, X. Internationalization and the performance of born-global SMEs: The mediating role of social networks. J. Int. Bus. Stud. 2007, 38, 673-690. [CrossRef]

103. Borcosi, C.A.; Stancut, A. Internationalization of SMEs-A solution to overcome the current economic crisis. Ann.-Econ. Ser. 2010, 4, 47-54.

104. Oparaocha, O. SMEs and international entrepreneurship: An institutional network perspective. Int. Bus. Rev. 2015, 24, 861-873. [CrossRef]

105. Caputo, M.; Pellegrini, M.M.; Dabić, M.; Dana, L.P. Internationalizing in the transition economies of Central and Eastern Europe. A systematic literature review approach. Eur. Bus. Rev. 2016, 28, 630-651. [CrossRef]

106. Dimitratos, P.; Johnson, J.; Plakoyiannaki, E.; Young, S. SME internationalization: How does the opportunity-based international entrepreneurial culture matter. Int. Bus. Rev. 2016, 25, 1211-1222. [CrossRef]

107. Törnroos, Å.; Kujala, I. Internationalizing through networks from emerging to developed markets with a case study from Ghana to the U.S.A. Ind. Mark. Manag. 2018, 69, 98-109.

108. Hsu, W.-T.; Chen, H.-L.; Cheng, C.-Y. Internationalization and firm performance of SMEs: The moderating effects of CEO attributes. J. World Bus. 2013, 48,1-12. [CrossRef]

109. Sui, S.; Baum, M. Internationalization strategy, firm resources and the survival of SMEs in the export market. J. Int. Bus. Stud. 2014, 45, 821-841. [CrossRef]

110. Yamin, M.; Kurt, Y. Revisiting the Uppsala internationalization model: Social network theory and overcoming the liability of outsidership. Int. Mark. Rev. 2018, 35, 2-17. [CrossRef]

111. Jardon, C.; Molodchik, M. What types of intangible resources are important for emerging market firms when going international? J. East Eur. Manag. Stud. 2017, 22, 579-595. [CrossRef]

112. Yener, M.; Doğruoğlu, B.; Ergun, S. Challenges of Internationalization for SMEs and Overcoming these Challenges: A Case Study from Turkey. Procedia Soc. Behav. Sci. 2014, 150, 2-11. [CrossRef]

113. Manolova, T.S.; Manev, I.M.; Gyoshev, B.S. Friends with money? Owner's financial network and new venture internationalization in a transition economy. Int. Small Bus. J. Res. Entrep. 2014, 32, 944-966. [CrossRef]

114. Hilmersson, M. Small and medium-sized enterprise internationalization strategy and performance in times of market turbulence. Int. Small Bus. J. 2014, 32, 386-400. [CrossRef]

115. Raymond, L.; St-Pierre, J.; Uwizeyemungu, S.; Le Dinh, T. Internationalization capabilities of SMEs: A comparative study of the manufacturing and industrial service sectors. J. Int. Entrep. 2014, 12, 230-253. [CrossRef]

116. Ngoma, M. Role of Resources in the Internationalization of Small and Medium Enterprises (SMEs). Bus. Manag. Rev. 2016, 18, 1-23.

117. Welbourn, T.M.; Pardo del Val, M. Relational capital: Strategic advantage for small and medium-sized enterprises (SMEs) negotiation and collaboration. Group Decis. Negot. 2009, 18, 483-497. [CrossRef]

118. Hernández-Trasobares, A.; Galve-Górriz, C. The influence of family control on decisions regarding the specialization and diversification of business groups. Bus. Res. Q. 2016, 19, 73-89. [CrossRef] 
119. Pérez-López, M.C.; Gómez-Miranda, M.E.; Argente-Linares, E.; López-Sánchez, L. The internationalization of Spanish family firms through business groups: Factors affecting the profitability, and the moderating effect of the family nature of the Spanish business. Span. Acc. Rev. 2018, 21, 82-90.

120. Rod, M.; El Banna, A.; Munim, A. SME Internationalization: A Critical Review of Non-Traditional Approaches. 2016. Available online: https://www.impgroup.org/uploads/papers/8911.pdf (accessed on 9 January 2019).

121. Mandysová, I. Motivation for Small and Medium-Sized Entrepreneurs for Internationalization on the European Union Market. J. Women's Entrep. Educ. 2010, 1-2, 71-80.

122. Davidkov, T.; Yordanova, D. Enhancing SME Internationalization in a Transition Economy: The role of Internal Factors. Int. J. Latest Trends Financ. Econ. Sci. 2015, 5, 945-956.

123. Perrigot, R.; López-Fernández, B.; Eroglu, S. Intangible Resources and Plural Form as Drivers of Franchise Internationalization: Examination within a Two Country Perspective. J. Small Bus. Manag. 2013, 51, 557-577. [CrossRef]

124. Pillai, K.G.; Hodgkinson, G.P.; Kalyanaram, G.; Nair, S.R. The Negative Effects of Social Capital in Organizations: A Review and Extension. Int. J. Manag. Rev. 2017, 19, 97-124. [CrossRef]

125. Antonie Nitu, R.; Feder, E.-S. Studiu privind factorii determinanti ai procesului de internationalizare a intreprinderilor mici si mijlocii din România" [A study concerning the main drivers of the internationalization process for Romanian SMEs]. Economie Teoretică si Aplicată [Theor. Appl. Econ.] 2010, XVII, 17-26.

126. Barkema, H.G.; Vermeulen, F. International expansion through start-up or acquisition: A learning perspective. Acad. Manag. J. 1998, 41, 7-26.

127. Lu, J.W.; Beamish, P.W. International diversification and firm performance: The s-curve hypothesis. Acad. Manag. J. 2004, 27, 598-609.

128. Ortiz, S. Visión y Gestión Empresarial-Cómo Articular las Estrategias y el Capital Humano para Triunfaren la Economía del Conocimiento, Colección Negocios; Thomson Editores: Madrid, Spain, 2003.

129. Xu, J.; Wang, B. Intellectual Capital, Financial Performance and Companies' Sustainable Growth: Evidence from the Korean Manufacturing Industry. Sustainability 2018, 10, 4651. [CrossRef]

130. Zucchella, A.; Palamara, G.; Denicoali, S. The drivers of early internationalization of the firm. J. World Bus. 2007, 42, 268-280. [CrossRef]

131. Barroso, C.; Villegas, M.M.; Perez-Calero, L. Board influence on a firm's internationalization. Corp. Gov. Int. Rev. 2011, 19, 351-367. [CrossRef]

132. Bontis, N. Managing Organizational Knowledge by Diagnosing Intellectual Capital: Framing and Advancing the State of the Field. Int. J. Technol. Manag. 1999, 18, 433-462. [CrossRef]

133. Yli-Renko, H.; Autio, E.; Tontti, V. Social capital, knowledge, and the international growth of technology-based new firms. Int. Bus. Rev. 2002, 11, 279-304. [CrossRef]

(C) 2019 by the authors. Licensee MDPI, Basel, Switzerland. This article is an open access article distributed under the terms and conditions of the Creative Commons Attribution (CC BY) license (http://creativecommons.org/licenses/by/4.0/). 